\title{
LINKING TEACHER PROFESSIONAL DEVELOPMENT NEEDS WITH APPROPRIATE SOLUTIONS: INSIGHTS FROM AN INIATIVE IN LATVIA
}

\author{
Kārlis Greitāns \\ University of Latvia, \\ The Interdisciplinary Center of Educational Innovations, Latvia \\ Dace Erina \\ University of Latvia, \\ The Interdisciplinary Center of Educational Innovations, Latvia

\section{Dace Namsone} \\ University of Latvia, \\ The Interdisciplinary Center of Educational Innovations, Latvia
}

\begin{abstract}
International surveys have stated that each year teachers spend, on average, more than 10 days engaged in different professional development activities. The purpose for this investment in teacher professional development (TPD) is clear: teachers' competence must develop according to changes in curriculum and $21^{\text {st }}$ century requirements.

In previous research we have developed a theoretical teacher competence framework, implemented it to identify teacher $(N=263)$ groups competence gaps and professional development needs. The goal of this research is to link identified professional development needs related to the instruction of $21^{\text {st }}$ century skills (criteria - instructional design, learning goals and feedback to students) with TPD solutions.

This paper describes the development of a TPD model, based on evidence about teacher groups professional development needs, and its implementation in a school ( $N=25$ teachers). A TPD program, developed according to the model, combined face-to-face and online input workshops with collaboration in small groups to develop lesson plans. The topics of input workshops, (effective lesson design, lesson goals, effective feedback and reading comprehension) were chosen according to gaps, previously identified. To learn about appropriateness of the TPD model, the developed lesson plans, participant questionnaires and researcher field notes were analysed.
\end{abstract}

Keywords: evidence-based professional development solutions, teacher collaborative professional learning, teacher professional development needs.

\section{Introduction}

Latvia like other countries is undergoing a curriculum reform (Nieveen, 2018) that has a focus on $21^{\text {st }}$ century skills, complex use of knowledge, skills, 
Greitāns et al., 2021. Linking Teacher Professional Development Needs with Appropriate Solutions: Insights from an Iniative in Latvia

attitudes and values. Thus, it becomes increasingly important to monitor if and how teachers plan and ensure the classroom learning and whether it aligns with the goals of the reform. This then provides information for planning and delivering the necessary professional development (PD) support.

School administration plays a key role in this process, however there is a lack of good practice how to make evidence-based decisions to link teacher PD needs with appropriate PD interventions that bring changes in classroom practice (Sims \& Fletcher-Wood, 2020).

In previous studies our research group has developed and validated a framework of teacher performance assessment (Bertule, Dudareva, \& Namsone, 2019), teacher knowledge tests and questionnaires to identify teacher competence gaps (Dudareva, Namsone, Butkēviča, \& Čakāne, 2019) and used these instruments to develop a methodology for identification and prioritization of teacher PD needs (Butkēviča, Namsone, \& Čakāne, 2021; Greitāns, Eriņa, \& Namsone, 2021). This paper describes our first attempts to link PD solutions, based in evidence about teacher PD needs, with appropriate PD forms and contents.

The aim of this research is to develop a content non-specific teacher PD model which links PD needs and interventions.

\section{Literature Review}

The Latvian general education system is undergoing a curriculum reform that is introducing $21^{\text {st }}$ century skills, also called transversal competencies (Latvijas Republikas Ministru kabinets, 2018). The guidelines of the curriculum reform (Skola2030, 2017) emphasize the role of evidence-based school development goals in the process of the implementation of the new curriculum. Furthermore, for schools to set the development goals related to the new curriculum, it becomes crucial to determine whether teachers have the necessary competencies to ensure that schools can reach these new goals. Therefore, it is critical to identify teacher competence gaps and their PD needs and what teacher PD solutions are required.

Conceptualization of teacher professional competence for teaching $21^{\text {st }}$ century skills is based on a multidimensional interplay of teacher knowledge, skills, attitudes that are learnable, and explain differences in teachers' performance (Kunter et al., 2013) and includes the situatedness of instruction (Kaiser et al., 2017). Research points out to a gap between teachers' actual and required competence where competence gap is obtained by comparing scores of two or more differently obtained assessment results (Febrianis, Muljono \& Susanto, 2014). 
To address teachers' PD needs for teaching $21^{\text {st }}$ century skills, various PD interventions have already been developed (Postholm, 2012). However, the evaluation of these interventions and their achieved effects has been found to be widely divergent (Merchie, Tuytens, Devos, \& Vanderlinde, 2016). High quality PD interventions provide a mixture of different phases: input, application, and reflection (Guskey, 1999, 145). Thus, high quality PD interventions combine seminar phases with learning on-job at school. In particular, they provide input on relevant topics, participants are able to implement this input in their daily work, and teachers reflect their professional competencies and beliefs (Borko, 2004). Here, opportunities for exchange with colleagues as well as feedback from the teacher educators and colleagues are essential. In particular, teacher tandems (colleagues from the same school, who jointly use a PD intervention) enable mutual support and feedback, which fosters the development of competencies. This leads to a virtuous circle of action and reflection, which makes PD interventions relevant for teaching practice (European Network of STEM PD Centres, 2019).

An PD intervention that has received recognition worldwide is Japanese lesson study. In this intervention teachers with a common focus meet, plan, conduct a research lesson and reflect about it (Fernandez \& Yoshida, 2004). In the last two decades researchers have implemented the principles of Japanese lesson study in different countries and proven that the PD trough lesson study:

- offers teachers the opportunity to develop ownership of the improvement effort, a commitment to inquiry, shared goals, and a sense of responsibility to their colleagues and students (Lewis, Perry, \& Hurd, 2009),

- $\quad$ gives teachers a chance to differentiate the PD according their needs (Perry \& Lewis, 2009, p. 388),

- enables teachers to build on their efforts and refine their understandings (Lewis et al., 2009).

In previous studies our research group has described the implementation of lesson study in primary teacher PD (Namsone, Čakāne, France, \& Butkēviča, 2016) to promote teaching of $21^{\text {st }}$ century skills. The research showed that primary teachers participating in a lesson-based professional development program with a strong continuous collaborative element gained an understanding of the importance of implementing 21st century skills in the classroom. Our research groups previous studies also describe development of The Framework of Teacher Performance Assessment to Support Teaching 21st Century Skills (Bertule et al., 2019), consisting of 8 categories (identified with "IA" or "IB") that are characterized with 13 criteria and structured in three domains of teaching practice - planning (1), teaching (2), classroom 
Greitāns et al., 2021. Linking Teacher Professional Development Needs with Appropriate Solutions: Insights from an Iniative in Latvia

environment (3). Validated performance level descriptors (PLDs) of these criteria were used in a qualitatively oriented lesson observation study in combination with tests and questionnaires filled online by teachers, whose lessons were observed, to determine teacher groups PD needs. The average performance of group teachers, which included the teacher sample researched in this paper, reached the required level regarding instructional design, however competence gaps regarded to learning goals and feedback were identified. These gaps should be crossed trough personalised and evidence-based PD interactions, at least in group level (Butkēviča et al., 2021).

The analysis of teacher groups competence gaps and professional development needs led authors to the goal of this research: to design a PD model to address teachers' PD needs regarding effective lesson design with a focus on learning goals and feedback to students. This paper describes first piloting of the model and its analysis trough evaluation of features of the model and participant learning.

Therefore, following research questions arise:

1. How to design PD model, based on teacher groups PD needs?

2. What first piloting results show about the features of the developed model and participant learning?

\section{Methodology}

Study sample consists of 3 sub-samples of grade 1 to 8 teachers: 10 primary school teachers (sub-sample 1: school A, municipality X, urban), 15 lower secondary school teachers (sub-sample 2: school A, municipality X, urban) and 40 lower secondary school teachers (sub-sample 3: school B, municipality X, urban). This paper describes results obtained from sub-samples $1 \& 2$.

In previous research our group has identified that teachers of sub-samples 1 \& 2 have PD needs to progress from level 1 to level 2 regarding criteria 1.1. \& 1.3. from the Framework of Teacher Performance Assessment to Support Teaching 21st Century Skills. To meet the schools A goal (to reach level 2 in criteria 1.1., 1.2.(metacognitive skills) \& 1.3.) we agreed with the school's administration to pilot this research and a PD program to cross teacher PD needs.

Design of the model was done through in-depth analysis of teacher lesson observations, teacher test and questionnaire data; in-depth analysis of student performance data from national level diagnostic tests, and trough consultations between experts, researchers, school administration and teachers. 
The design of the model was done according to the principles of designbased implementation research (Fishman, Penuel, Allen, Cheng, \& Sabelli, 2013).

The following principles were set at the beginning of the model development. The PD model and programs designed according to it should such features as:

- regular input workshops combined with regular opportunities to implement the input in classroom practice, analyse and reflect about it,

- teacher collaboration,

- contents to deepen teacher understanding according to their PD needs.

A PD program developed according to the model was implemented in the school A from August 2020 to December 2020. The first two workshops were organised face-to-face, the concluding two - online. The input workshops included following learning forms: a short lecture, an individual or group task (i.e., analysis of lesson video recordings or documents), discussions (individual or group forms were chosen according to content) and Q\&A sessions.

Between the workshops' the 25 participants collaborated in 9 small groups (2 to 3 teachers) to create three lesson plans, observed and analysed each other's lessons. Following guidelines for collaboration were set: after the workshop the group collaborates to design a research lesson plan, which includes reading literacy. The group choses one teacher who has to lead the research lesson. Throughout the program each participant has to lead at least one research lesson, which is observed and transcripted by the rest of the group. After the research lesson the group meets to give feedback and to discuss improvements. Before the input workshop the group has to submit the lesson plan and a short report of their analysis. Participants received feedback and questions for reflection from workshop leaders to improve their plans.

Evaluation of the model was done according to the extended framework for evaluation of teachers' professional development initiatives (Merchie et al., 2016).

Selected short answer questions from the participant questionnaire, expert field notes and submission of lesson plans were used to triangulate the evaluation of following features of the model: collaborative lesson study, input workshops \& forms of online and face-to-face learning, workshop leader feedback.

Selected Likert-scale type questions from the participant questionnaire, expert field notes and analysis of lesson plans were used to triangulate the evaluation of participant learning throughout the program.

Field work: 4 experienced (7-17 yrs) and trained experts observed the implementation of the developed model from August 2020 till December 2020. 
Greitāns et al., 2021. Linking Teacher Professional Development Needs with Appropriate Solutions: Insights from an Iniative in Latvia

Participant questionnaire: contained 4 Likert-scale type questions (on a scale from 5-0, where 5 stands for "yes, agree completely" and 0 - "definitely not") and 4 short answer questions regarding participant experience and satisfaction throughout the program.

Participant lesson plan analysis: done according to validated performance level descriptors (PLDs), on a scale from 0 to 4 , of criteria 1.1. (learning goals), 1.3. (feedback to students) and 5.1. (lesson design) from the Framework of Teacher Performance Assessment to Support Teaching 21st Century Skills. The criterion 5.1. was chosen to confirm the findings of our previous research, that teachers of the study sample have reached the desired level in this criterion. The other two criteria - to evaluate teacher learning. Additionally, for this study PLDs for the level 3 and 4 are combined into one 3+ level.

Limitations of the research: The participant lesson plans were assessed by 3 experts; interrater reliability has not been calculated. Due to restrictions caused by COVID-19 pandemic part of the implementation of the model and teacher collaboration was carried out online.

\section{Research Results}

\section{How to design TPD model, based on teacher groups PD needs?}

The initial PD model, developed according to selected methodological principles, is visualised in Figure 1.

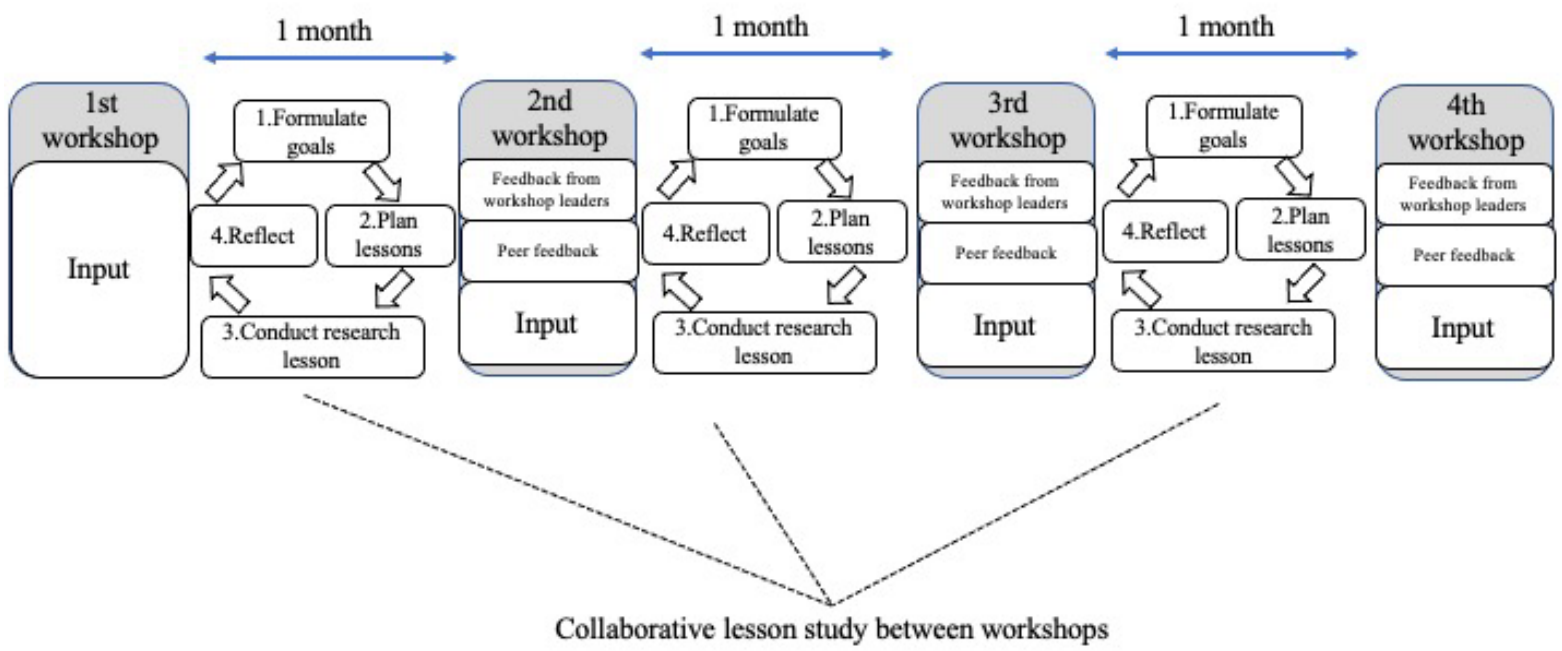

Figure 1 The Developed PD Model [created by authors]

The developed model and analysis of schools A teacher PD needs, student performance data from national level diagnostic tests, and consultations between 
researchers and schools A administration were used to develop a pilot PD program.

The developed pilot PD program was aimed to:

- $\quad$ promote teacher understanding of effective lesson design with a focus on learning goals and formative assessment,

- implement the contents of the program in classroom practice,

- $\quad$ promote student reading literacy.

The planning of the pilot PD program started with selection of general contents of the program according to the aims set. The topics and curriculumrelated context for the input workshops (Table 1) were selected according to previously identified teacher PD needs in criteria 1.1. \& 1.3. (topics 1-3) and student learning needs. The student learning needs regarding reading literacy was chosen based on analysis of schools A student performance data from national level diagnostic tests of previous 2 school years.

Table 1 General Content of the Program

\begin{tabular}{|l|l|l|l|}
\cline { 2 - 4 } \multicolumn{1}{c|}{} & \multicolumn{1}{c|}{$\begin{array}{c}\text { Topic 1: } \\
\text { Lesson design }\end{array}$} & \multicolumn{1}{c|}{$\begin{array}{c}\text { Topic 2: } \\
\text { Learning goals }\end{array}$} & \multicolumn{1}{c|}{$\begin{array}{c}\text { Topic 3: } \\
\text { Formative } \\
\text { assessment }\end{array}$} \\
\hline $\begin{array}{l}\text { Contents } \\
\text { selected } \\
\text { regarding } \\
\text { teacher PD } \\
\text { needs }\end{array}$ & $\begin{array}{l}\text { Backwards design in lesson } \\
\text { planning. Features of an } \\
\text { effective lesson. Principles } \\
\text { of lesson study. Teacher } \\
\text { collaboration throughout } \\
\text { lesson study. }\end{array}$ & $\begin{array}{l}\text { SMART criteria. } \\
\text { Communication of } \\
\text { learning goals to } \\
\text { students. }\end{array}$ & $\begin{array}{l}\text { Principles of } \\
\text { formative } \\
\text { assessment. } \\
\text { Feedback in lesson. }\end{array}$ \\
\hline $\begin{array}{l}\text { Contents } \\
\text { selected } \\
\text { regarding } \\
\text { student needs }\end{array}$ & $\begin{array}{l}\text { The concept and structure of } \\
\text { reading literacy. Teacher } \\
\text { collaboration to promote } \\
\text { reading literacy }\end{array}$ & $\begin{array}{l}\text { Student skills related } \\
\text { to reading literacy. } \\
\text { Reading literacy in } \\
\text { lesson. }\end{array}$ & $\begin{array}{l}\text { Using reading } \\
\text { literacy assessment } \\
\text { rubrics in formative } \\
\text { assessment }\end{array}$ \\
\hline
\end{tabular}

\section{What first piloting results show about the features of the developed model and participant learning?}

\section{Features of the developed model}

Although teachers had no previous experience in collaborative lesson studies, they were satisfied with this experience. 16 of 25 participants evaluated the collaborative lesson study as successful, 7 - as almost successful. 16 of 25 participants described their experience during research lessons as successful or without difficulties. 6 of 25 teachers described their experience in collaborative lesson planning during the lesson study as successful or without difficulties. 
Greitāns et al., 2021. Linking Teacher Professional Development Needs with Appropriate Solutions: Insights from an Iniative in Latvia

Most of teachers - 13 mentioned, that lesson planning during the lesson study required additional time. Throughout the program, all groups followed the guidelines for collaboration and submitted their lesson plans timely.

Most participants mentioned lesson video analysis (20 mentions) as a successful form of learning. 9 participants mentioned difficulties regarding forms of online learning or use of ICT. 18 participants stated that online learning caused no difficulties or improved their experience. During the field work experts noted that teachers of sub-sample 2 participated in the input workshops more actively than teachers of sub-sample 1 . According to experts, teachers of sub-sample 2 also stated deeper questions and reflected about their practice more critical.

\section{Participant learning}

Expert notes confirmed that the samples teachers have sufficient prior understanding in instructional design. The lesson plan analysis (Table 2) confirmed that: 3 of 4 teacher groups from sub-sample 1 and all 5 teacher groups representing sub-sample 2 reached the required level in lesson design in the last two lesson plans submitted. 3 sub-samples 2 teacher groups even progressed to level 3+ in the last lesson plan submitted.

Table 2 Comparison of Sub-sample Performance in Lesson Plans

\begin{tabular}{|l|c|c|c|c|c|c|c|}
\cline { 2 - 9 } \multicolumn{1}{c|}{ Criteria } & \multicolumn{2}{c|}{ 2nd lesson plan } & \multicolumn{2}{c|}{ 3rd lesson plan } & Total teacher \\
groups
\end{tabular}

According to questionnaire (Table 3), teachers also strongly agree that they understand effective lesson design.

Table 3 Participant Answers to Likert-scale Questions Regarding Their Understanding

\begin{tabular}{|l|l|}
\hline Statement & $\begin{array}{l}\text { Response } \\
\text { (Max. 5.00) }\end{array}$ \\
\hline I understand the effective lesson design. & 4.45 \\
\hline $\begin{array}{l}\text { I can explain with examples, how to state learning goals according to } \\
\text { SMART criteria. }\end{array}$ & 4.39 \\
\hline I have gained understanding about formative assessment. & 4.29 \\
\hline I have gained understanding about student reading literacy. & 4.55 \\
\hline
\end{tabular}

$n=25 ;$ Cronbach's alpha $=0.76$ 
Expert notes indicated that in the second workshop participants showed understanding about learning goals through questions and discussions. The lesson plan analysis (Table 3) confirmed that: already in the second lesson plan 3 of 4 teacher groups from sub-sample 1 and 4 of 5 teacher groups representing sub-sample 2 reached the required level in learning goals. According to questionnaire (Table 2), teachers also strongly agree that they understand how to state learning goals.

Expert notes showed that formative assessment was a challenge to samples teachers. Experts noted that participant comments, discussions and questions showed partial or no understanding regarding about feedback. The lesson plan analysis (Table 3) confirmed challenges in implementation of effective feedback into lessons. at the end of the program only one group from sub-sample 1 and two groups from sub-sample 2 reached the required level in feedback. However, these results can be viewed as a progress, because no groups reached the required level in this criterion before. The questionnaire answers (Table 2) showed that participants rate their understanding highly, however lower compared to understanding about other topics.

\section{Conclusions and Discussion}

A PD model that includes 4 input workshops and collaborative lesson studies between them was developed. Regular input workshops combined with regular opportunities to implement the input in classroom practice, teacher collaboration and contents to deepen teacher understanding according to their PD needs were the key principles in the development of the model.

To pilot the model, a PD program, which links schools aims and identified teacher PD needs with appropriate contents and solutions was developed. The PD program was piloted in one school with the aim to deepen teachers understanding in effective lesson design with a focus on learning goals and feedback. Piloting confirms the practical applicability of the model and a successful interplay between input workshops, classroom practice and its analysis. The model and the program developed according to it was piloted with primary and lower secondary school teachers. Further applicability with different teacher groups and contents should be researched.

The piloting of the model showed that lower secondary school teachers progressed in their understanding faster than primary school teachers. The results once more highlight that it is challenging for teachers to implement information about process and self-regulation in feedback. The combination of between programs contents and chosen PD forms should be researched to create more effective PD interventions for primary school teachers. 
Greitāns et al., 2021. Linking Teacher Professional Development Needs with Appropriate

Solutions: Insights from an Iniative in Latvia

\section{Acknowledgements}

This research is supported by the Latvian Council of Science project "Innovative solutions in assessing teacher competencies for personalized professional learning”, No. lzp-2019/1-0269

\section{References}

Bertule, D., Dudareva, I., \& Namsone, D. (2019). Framework of Teacher Performance Assessment to Support Teaching 21st Century Skills. Proceedings of the 13th annual Conference International Technology, Education and Development (INTED), Valencia, Spain, 11.-13.03.2019., 5742-5752. DOI: 10.21125/inted.2019.1410

Borko, H. (2004). Professional Development and Teacher Learning: Mapping the Terrain. Educational Researcher, 33(8), 3-15. https://doi.org/10.3102/0013189x033008003

Butkēviča, A., Namsone, D., \& Čakāne, L. (2021). Identification of professional development needs of a group of teachers for attaining school goals. The 19th Biennial EARLI Conference, Education and Citizenship: learning and instruction and the Shaping of Futures, In publishing.

Dudareva, I., Namsone, D., Butkēviča, A., Čakāne, L. (2019). Assessment for identifying teacher competence gap in the context for improving teaching 21st century skills. Proceedings of the 12th Annual International Conference of Education, Research and Innovation (ICERI), Seville, Spain, 11.-13.11.2019., 5555-5563.

European Network of STEM PD Centres. (2019). How can we measure the impact of a PD activity? Ready-to-use guidelines. Retrieved from https://stem-pd-net.eu/wpcontent/uploads/2019/07/IO2_EvaluationMethods_190705_final.pdf

Febrianis, I., Muljono, P., \& Susanto, D. (2014). Pedagogical competence-based training needs analysis for natural science teachers. Journal of Education and Learning, 8(2), 144-151.

Fernandez, C., \& Yoshida, M. (2004). Lesson study: A case of a Japanese approach to improving instruction through school-based teacher development. Mahwah, NJ: Lawrence Erlbaum.

Fishman, B.J., Penuel, W.R., Allen, A., Cheng, B., \& Sabelli, N. (2013). Design-based implementation research: An emerging model for transforming the relationship of research and practice. National society for the study of education, 112 (2), 136-156.

Greitāns, K., Eriṇa, D., \& Namsone, D. (2021). How to prioritize STEM teachers professional development needs to plan evidence-based professional development solutions? The 14th Conference of the European Science Education Research Association (ESERA2021), In Publishing.

Guskey, T. R. (2000). Evaluating Professional Development (1st ed.). Thousand Oaks. California: Corwin Press.

Kaiser, G., Blömeke, S., Koenig, J., Busse, A., Doehrmann, M., \& Hoth, J. (2017). Professional competencies of (prospective) mathematics teachers-Cognitive versus situated approaches. Educational Studies in Mathematics, 94(2), 161-182.

Kunter, M., Klusmann, U., Baumert, J., Richter, D., Voss, T., \& Hachfeld, A. (2013). Professional competence of teachers: Effects on instructional quality and student development. Journal of Educational Psychology, 105(3), 805-820. 
Lewis, C. C., Perry, R. R., \& Hurd, J. (2009). Improving mathematics instruction through lesson study: A theoretical model and North American case. Journal of Mathematics Teacher Education, 12, 285-304. DOI: 10.1007/s10857-009-9102-7.

Merchie, E., Tuytens, M., Devos, G., \& Vanderlinde, R. (2016). Evaluating teachers' professional development initiatives: towards an extended evaluative framework. Research Papers in Education, 33(2), 143-168. https://doi.org/10.1080/ 02671522.2016.1271003

Namsone, D., Čakāne, L., France, I., ～\& Butkēviča, A. (2016). Lessonbased Professional Development: Helping Primary Teachers Teach $21^{\text {st }}$ Century Skills. Proceedings of the 9th annual International Conference of Education, Research and Inn ovation (ICERI), Seville, Spain, 14.-16.11.2016, 3892-3902. DOI: 10.21125/iceri.2016

Nieveen, N., \& Plomp, T. (2018). Curricular and Implementation Challenges in Introducing Twenty-First Century Skills in Education, In Care, Griffin, Wilson (Ed.), Assessment and Teaching of 21st Century Skills, (259-276). Cham: Springer.

Perry, R. R., \& Lewis, C. C. (2009). What is successful adaptation of Lesson Study in the U.S.? Journal of Educational Change, 10(4), 365-391. DOI: 10.1007/s10833-0089069-7.

Postholm, M. B. (2012). Teachers' professional development: a theoretical review. Educational Research, 54(4), 405-429. DOI: 10.1080/00131881.2012.734725.

Latvijas Republikas Ministru kabinets. (2018). Noteikumi Nr. 747 Noteikumi par valsts pamatizglìtības standartu un pamatizglìtības programmu paraugiem. Pieejams https://likumi.lv/ta/id/303768

Skola2030. (2017). Education for contemporary competence: description of curricula and approach (reform document for public consultation, in Latvian). Retrieved from https://docs.wixstatic.com/ugd/3e1e8c_0b2ac53576544b70a2b689edcfbef010.pdf

Sims, S., \& Fletcher-Wood, H. (2020). Identifying the characteristics of effective teacher professional development: a critical review. School Effectiveness and School Improvement, 1-17. DOI: 10.1080/09243453.2020.1772841 